University of Windsor

Scholarship at UWindsor

2000

\title{
The spatial response of male hooded warblers to edges in isolated fragments
}

\author{
Ryan D. Norris \\ University of Windsor \\ Bridget J.M. Stutchbury \\ University of Windsor \\ Trevo E. Pitcher \\ University of Windsor
}

Follow this and additional works at: https://scholar.uwindsor.ca/biologypub

Part of the Biology Commons

\section{Recommended Citation}

Norris, Ryan D.; Stutchbury, Bridget J.M.; and Pitcher, Trevo E., "The spatial response of male hooded warblers to edges in isolated fragments" (2000). The Condor, 102, 3, 595-600.

https://scholar.uwindsor.ca/biologypub/1156

This Article is brought to you for free and open access by the Department of Biological Sciences at Scholarship at UWindsor. It has been accepted for inclusion in Biological Sciences Publications by an authorized administrator of Scholarship at UWindsor. For more information, please contact scholarship@uwindsor.ca. 


\title{
THE SPATIAL RESPONSE OF MALE HOODED WARBLERS TO EDGES IN ISOLATED FRAGMENTS
}

\author{
Author(s): D. Ryan Norris, Bridget J. M. Stutchbury, Trevor E. Pitcher \\ Source: The Condor, 102(3):595-600. \\ Published By: Cooper Ornithological Society \\ https://doi.org/10.1650/0010-5422(2000)102[0595:TSROMH]2.0.CO;2 \\ URL: http://www.bioone.org/doi/full/10.1650/0010-5422\%282000\%29102\%5B0595\%3ATSROMH \\ $\% 5 \mathrm{D} 2.0 . \mathrm{CO} \% 3 \mathrm{~B} 2$
}

BioOne (www.bioone.org) is a nonprofit, online aggregation of core research in the biological, ecological, and environmental sciences. BioOne provides a sustainable online platform for over 170 journals and books published by nonprofit societies, associations, museums, institutions, and presses.

Your use of this PDF, the BioOne Web site, and all posted and associated content indicates your acceptance of BioOne's Terms of Use, available at www.bioone.org/page/terms of use.

Usage of BioOne content is strictly limited to personal, educational, and non-commercial use. Commercial inquiries or rights and permissions requests should be directed to the individual publisher as copyright holder. 


\title{
THE SPATIAL RESPONSE OF MALE HOODED WARBLERS TO EDGES IN ISOLATED FRAGMENTS ${ }^{1}$
}

\author{
D. Ryan Norris, Bridget J. M. Stutchbury and Trevor E. Pitcher ${ }^{2}$ \\ Department of Biology, York University, 4700 Keele St., North York, ON, Canada M3J 1P3, \\ e-mail:drnorris@yorku.ca
}

\begin{abstract}
We tested whether Hooded Warblers (Wilsonia citrina) avoided abrupt forest edges by radiotracking males breeding in small, isolated forest patches (0.5-2.0 ha) in northwest Pennsylvania. Because territory edges were synonymous with abrupt forest edges in all cases, we compared space use patterns with males radiotracked in a nearby continuous forest (150 ha), where we defined edge from territorial boundaries. Based on the proportion of edge to core area, males in both habitats avoided the area within $20 \mathrm{~m}$ of the edge, implying that males responded to the presence of territory edge rather than forest edge. Surprisingly, however, males in isolated fragments used the edge area significantly more than males in continuous forest, even when measured against the relative amount of edge area within each territory. Elevated levels of edge use were not related to distance of nests to edges, nest stage, or time of day. We conclude that the presence of physical edges is not the sole determinant of territorial space use in this species and there are likely additional social factors influencing occupancy rates in small, isolated woodlots. Therefore, definitions of forest-interior species based on edge use need to be reconsidered.
\end{abstract}

Key words: edge use, forest-interior, fragmentation, Hooded Warbler, isolation, territorial space use, Wilsonia citrina.

\section{INTRODUCTION}

Forest edges in fragmented landscapes, commonly defined by shape transition zone between forested habitat and developed land (Murcia 1995), are recognized to have detrimental effects on nesting success of Neotropical migrant forest birds (Gates and Gysel 1978, Brittingham and Temple 1983, Wilcove 1985). However, some birds such as American Redstart Setophaga ruticilla (Sodhi et al. 1999), Wood Thrush Hyocichla mustelina (Weinberg and Roth 1998), and Hooded Warbler Wilsonia citrina (this study) successfully breed in extremely small fragments $(<2.0$ ha $)$ despite their apparent preference for forest-interior habitat. The spatial response of forest species to edges is unknown but could be an important indicator of habitat suitability (Wenny et al. 1993). Some studies have suggested that adult birds may avoid edges due to an increase risk of predation (Huhta et al. 1998) or changes in microclimatic features (Møller 1991). Surprisingly, knowledge of how breeding birds use edges is limited to presence/ absence studies (Noss 1991, Yahner 1995). This

\footnotetext{
${ }^{1}$ Received 8 September 1999. Accepted 3 April 2000.

${ }^{2}$ Current address: Department of Zoology, University of Toronto, 25 Harbord St., Toronto, ON, Canada M5S 3G5.
}

is largely due to the difficulty of accurately documenting the daily movements of birds over an entire breeding season (Desrochers et al. 1999).

In this paper, we measure the spatial response of breeding adult male Hooded Warblers to forest edge in isolated forest fragments using radio telemetry. Hooded Warblers are 11-g Neotropical migrants that are considered an area-sensitive, forest-interior species (Noss 1991, Freemark and Collins 1992). Whitcomb et al. (1981) used point count surveys and found Hooded Warblers occurred significantly more in forests larger than 70 ha. Blake and Karr (1987) found Hooded Warblers to occur only in the largest tract of forest (600 ha). Using 500 Breeding Bird Survey routes, Robbins (1979) determined the minimum area required to sustain a breeding population was 30 ha. Noss (1991) delimited boundaries of Hooded Warblers in Florida and found this species avoids forest edges significantly more than if they were randomly dispersed.

To investigate the spatial response of Hooded Warblers to the edge interface between isolated forest and non-forest habitat, we radiotracked breeding males holding territories encompassed entirely within small forest islands, similar to the size of territories held by males in a continuous forest. Because of the hypothesized importance of forest edge effects, we predicted that males 


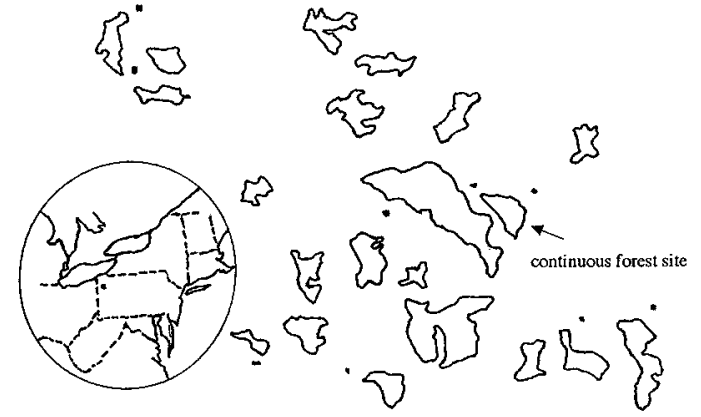

FIGURE 1. Map of the entire study area, encompassing isolated woodlots (solid black) and continuous forest (indicated with arrow) used by Hooded Warblers. Other than study areas, only large forested areas are shown. The map in the bottom left shows the regional location of the study area.

should avoid the edge in relation to total available area.

Because territory edge was synonymous with abrupt forest edges in isolated woodlots, we attempted to distinguish between "territorial edge" responses and "forest edge" responses. For example, birds may spend more time away from territorial edges because loss of core area is more likely to lead to total loss of territories, or valuable resources may be concentrated closer to the center of territories (Giraldeau and Ydenberg 1987). Edge use, therefore, could be influenced by either ecological or social factors (competition with neighbors). Only through a comparison with males in continuous forest, where territory edges do not coincide with forest edges, can we assess whether the degree of edge use by males in forest fragments is a result of forest edge effects. Therefore we also radiotracked males in a continuous (150 ha) forest with territorial edges but no forest edges. We tested the null hypothesis that males in both habitats should spend equal amounts of time on the edge versus the core of their territories in relation to the total area.

\section{METHODS}

The study area was located in a mosaic landscape of agricultural field and forest in Crawford County, northwestern Pennsylvania $\left(41^{\circ} 46^{\prime} \mathrm{N}\right.$, $\left.79^{\circ} 56^{\prime} \mathrm{W}\right)$. We radiotracked males in isolated forest fragments $(n=10)$ and a nearby continuous (150 ha) forest $(n=10)$ from May to July, 1997-1999 (Fig. 1). Both isolated patches and continuous forest were composed of mature mixed hardwood-deciduous forest. Breeding success (number of young fledged) and brood parasitism by Brown-headed Cowbirds (Molothrus ater) were similar between continuous forest and isolated fragments (Norris and Stutchbury, unpubl. data).

Territorial males were caught in mist nets with playbacks, and fitted with Holohil BD-2B (0.67 g) radio transmitters (Holohil Systems, Ltd., Carp, Ontario, Canada). Transmitters were attached to males via a figure-eight harness made with lightweight tubing or string. The loops of the harness fit around the legs so that the transmitter sat on the synsacrum and a 14-cm whipantenna followed above and past the tail. See Rappole and Tipton (1991) for details on harness construction and attachment. Transmitters do not affect behavior or reproductive success (Neudorf et al. 1997, Stutchbury 1998). Radio-tagged males were ground tracked with a receiver (Lotek Systems, Inc., Newmarket, Ontario, Canada) and a hand-held Yagi antenna. Males were followed quietly from a distance of approximately 30 to $40 \mathrm{~m}$ during four separate $2-\mathrm{hr}$ sessions beginning at 06:00 and ending at 14:00. Locations of males were recorded at 1-min intervals in the field using grid markers in the forest every $50 \mathrm{~m}$. Telemetry locations and distances from edge were later mapped to confirm accuracy.

We selected forest patches ( $n=9$, two males were radiotracked in the same fragment) that were bordered by agricultural fields and were isolated from larger forests except by small corridors less than $40 \mathrm{~m}$ wide ( $n=5$ woodlots). Edges at the interface between forest patches and agricultural fields were consistent in origin (human-caused) and structure (having an abrupt transition zone 5-10 $\mathrm{m}$ wide that contained dense understory shrubs, mainly rubus spp., 5$7 \mathrm{~m}$ in height).

To ensure that interactions between conspecifics related to territorial boundaries did not influence movement behavior related to forest edge boundaries, we only radiotracked males that were the sole occupants of an isolated fragment. Therefore, territories of males encompassed the entire fragment but always occurred within a single fragment (did not overlap between forest patches). Mean ( \pm SE) distance to nearest forest was $101 \pm 29 \mathrm{~m}(n=9$, range $=$ 40-250) in all fragments studied, and forest fragment sizes ranged from 0.71 to $1.98 \mathrm{ha}$.

In the 150-ha plot, radio-tagged males had at 


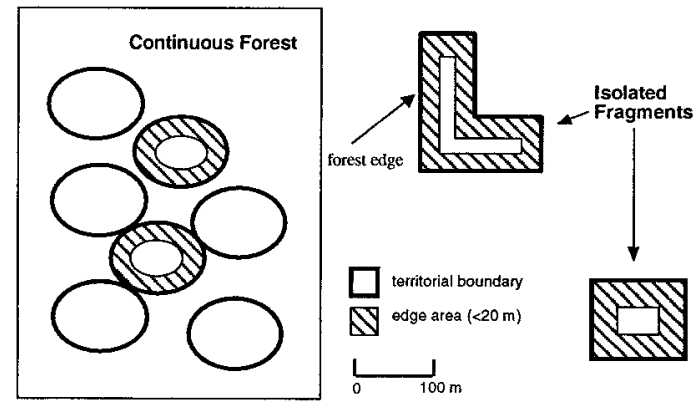

FIGURE 2. Schematic diagram of the two study habitats of Hooded Warblers. Isolated fragments $(\bar{x}=1.4$ \pm 0.1 ha, $n=10$ ) were similar in size to territories in continuous forest $(\bar{x}=1.1 \pm 0.1$ ha, $n=10, P>0.5)$. For males in isolated woodlots, territorial edge equaled forest edge. Fragments were farther apart than they appear but were generally similar shapes as the examples illustrated above. The actual boundary of continuous forest is larger than depicted.

least two neighbors and no territories bordered forest edges (Fig. 2). Territory boundaries were mapped based on singing output throughout the breeding season (not solely from radiotracking sessions), and averaged a radius of approximately $120 \mathrm{~m}$ (similar to Stutchbury 1988). Distance from the edge of the territory was calculated from mapped territorial boundaries based on grid markers in the field. Song rate and song bouts were recorded for all radiotracked males. We did not include space use or song behavior data when males left their territories to seek extra-pair copulations (Stutchbury 1998).

Edge area was defined as anywhere from 0 to $20 \mathrm{~m}$ inwards from the abrupt field/forest boundary in isolated woodlots (starting point of measurement began at the trunk of last tree [ $>30$ $\mathrm{dbh}$ ] on the edge) and from defined territorial boundaries in continuous habitat. Based on total use and singing output, territorial boundaries in isolated woodlots were synonymous with the edge of the woodlot itself. We chose $20 \mathrm{~m}$ as a maximum area that we could distinguish edge from core areas. Defining edge based on any distance greater than this would mean that effects would go undetected because small woodlots would be almost completely encompassed by edge area.

Time on edge was calculated from radio telemetry sessions and expressed as a percentage of total time spent on territory. We calculated the size of each fragment as well as the area inside $20 \mathrm{~m}$ of the edge. Geo-referenced points were taken in the field using a hand-held Global Positioning System (Magellan, Inc., Santa Clara, California) and downloaded into a Geographic Information System (SPANS 1998, version 7.1, Tydac Technologies Inc., Ottawa, Ontario, Canada) to determine area and perimeter of each woodlot. We then created $20-\mathrm{m}$ modified buffer zones to determine edge area and core area within individual woodlots.

\section{DATA ANALYSIS}

We calculated the proportion of edge based on the total area in each fragment/territory. To determine relative edge use, the percentage time spent on the edge was expressed as a function of this value. Means ( \pm SE) were derived from averages of individual males. We used nonparametric tests because of unequal variance between data sets (Zar 1996). One-tailed tests were used to investigate whether males in fragments avoided edge in relation to amount of edge area. Two-tailed tests were used to compare edge use between habitat types. All statistical tests were carried out at the 0.05 significance level.

\section{RESULTS}

\section{FOREST FRAGMENTS}

We radiotracked 10 males in nine isolated woodlots for a total of $139 \mathrm{hr}(\bar{x}=13.9 \pm 1.6 \mathrm{hr})$. Woodlots ranged in size from 0.7 to 2.0 ha with an average perimeter of $518 \pm 22 \mathrm{~m}$. All radiotracked males were mated and all nests were within the same woodlots as focal males. Data were collected from two males in the same woodlot but they were mated to different females and were radiotracked at separate times during the season.

We tested our null hypothesis, which stated that males should spend equal amounts of time in the center versus the edge of their territory proportional to the amount of area in each. The mean percent time males spent on the edge was $34.5 \pm 4.7 \%(n=10)$. There was no significant difference among individuals (Kruskal-Wallis single factor analysis of variance, $H=10.8, P$ $=0.2$ ), so we pooled data. Time spent on edge did not vary between fertile, incubating, or nestling stages or between the four time periods that males were radiotracked (Fig. 3). Mean distance to edge for nests $(\bar{x}=46.4 \pm 9.7 \mathrm{~m})$ was not correlated with the percentage time males spent on the edge $\left(r_{\mathrm{s}}=-0.370, n=10, P>0.05\right)$, therefore, we pooled data from all males. 

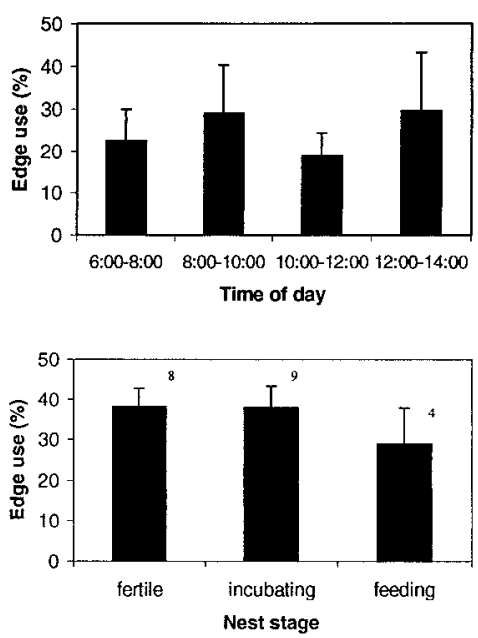

FIGURE 3. Top: Percent edge use ( \pm SE) during four time intervals corresponding to periods during which radiotracking of Hooded Warblers took place. Each time interval had $n=4$ individuals with data points. There was no significant difference between the four periods $(H=3.55, P=0.3)$. Bottom: Percent edge use $( \pm$ SE) did not vary between nest stages $(H$ $=0.98, P=0.6$ ). Sample sizes of individuals radiotracked in each stage are given above bars.

Average amount of edge area was 9,733 \pm $698 \mathrm{~m}^{2}$, which comprised a mean of $71.5 \pm$ $2.2 \%$ of the total woodlot area. Therefore, based on the proportional area of edge to the total area in each male's territory, the actual amount of time spent near the edge was significantly less than the expected time (Wilcoxon signed rank test; isolated: $T=2.8, P<0.005)$.

\section{COMPARISON WITH CONTINUOUS FOREST}

Ten males were radiotracked in continuous forest for a total of 194 hours $(\bar{x}=19.4 \pm 1.9)$. Territory sizes in continuous forest were similar to sizes of isolated woodlots (Fig. 2). Both the perimeter $(\bar{x}=416 \pm 24 \mathrm{~m})$ and edge area $(6,720 \pm 511 \mathrm{~m})$ of territories in continuous forest, however, were smaller than territories in isolated fragments (perimeter: $U=86, P<0.01$; edge area: $U=85, P<0.01$ ). This is likely attributable to the irregular shape of some isolated woodlots. Similar to males in isolated fragments, males in continuous forest spent less amounts of time $20 \mathrm{~m}$ from the edge than expected (Wilcoxon signed rank test: $T=2.8, P$ $<0.005)$.

However, mean percent time males spent within $20 \mathrm{~m}$ of the edge in continuous forest territories was $11.3 \pm 3.6 \%(n=10)$, which was significantly lower compared to males in fragments $(U=90, P<0.05)$. The percentage difference between actual and expected time spent on the edge was calculated to obtain a single value for each male. This value gave a measure of edge use based on the relative amount of edge area; this varied depending on the shape of the territory/fragment. A value lower than 1.0 indicated that a male did not spend as much time on edge as expected. All males had values lower than 1.0; however, there was a significant difference between continuous forest $(\bar{x}=0.17 \pm$ $0.03)$ versus fragments $(\bar{x}=0.49 \pm 0.06, U=$ $90, P<0.05)$, indicating that, although males in both habitats spend less time on their territory edge than expected, males in isolated woodlots spend relatively more time on the edge than males in continuous habitat.

\section{DISCUSSION}

Forest-interior birds are thought to avoid small forest islands, primarily because of an abundance of edge habitat (Wenny et al. 1993). This study is the first to measure edge use of adults over an entire breeding season. Results showed that males in isolated woodlots avoided the forest edges in relation to the total area of fragments. Nevertheless, males spent $35 \%$ of their time within $20 \mathrm{~m}$ of the forest boundary. Surprisingly, males in continuous habitat avoided their territorial boundaries to an even greater degree (only $11 \%$ of their time spent within $20 \mathrm{~m}$ ) despite their territorial edge being within forested habitat. When relative amount of edge area in each territory was taken into account, these values remained similar for both males in fragments and continuous forest $(49 \%$ and $17 \%$, respectively). This is contrary to our initial hypothesis that predicted males in isolated woodlots would avoid edge to a greater degree than males in continuous forest.

Hooded Warblers avoid forest edges, but we did not find any evidence that this was due to higher predation or reduction in prey abundance from changes in microclimatic features. No mortality resulted from males spending time near the edge in 139 hours of radiotracking, or as part of a larger study in which an additional 10 males were tracked for $119 \mathrm{hr}$ (Norris and Stutchbury, unpubl. data). Although we did not measure microclimatic variables, males spent extensive amounts of time near the edge where we fre- 
quently observed them foraging in low shrubs or high in the canopy while we were radiotracking.

Unexpectedly, males in fragments used their territory/forest edge more than males in continuous forest used their territory edge. This contradicts the idea that Hooded Warblers avoid forest edges due to poor microhabitat conditions or higher predation. Our findings that males in both habitats spent more time in the core than edge supports the strategic-center hypothesis (Giraldeau and Ydenberg 1987). This hypothesis predicts that males should spend more time in the core of their territory because loss of this area is more likely to lead to complete territorial loss. This hypothesis also can explain why isolated males spent so much time near the edge. Time spent in the core should increase with conspecific density because the threat of territory loss increases with increasing competition from nearby neighbors. Males in continuous habitat had a high median number of adjacent neighbors (three), while spending significantly more time in the core of their territory than males in isolated habitat. Furthermore, the only male with a single neighbor also had the highest territorial edge use (26\%).

In contrast, males in isolated patches spent less time in the core of their territory where closest neighbors were a minimum of $140 \mathrm{~m}$ away in adjacent woodlots. However, there was no correlation between mean distance to the next nearest active nest and amount of time spent on the edge $\left(r_{\mathrm{s}}=0.36, n=7, P>0.5\right)$. Due to the low power of this analysis (we could confirm the presence of active nests in seven cases) and the low variation in the number of neighbors in continuous forest (1-4), our evidence cannot adequately support the strategic-center hypothesis. We can conclude, however, that edge use in isolated woodlots is likely determined by social factors, not solely from effects of forest edges.

Further experimental manipulations are needed to investigate the effect of density on territorial space use patterns. Although it was not possible in this study, future research should consider tracking individuals in continuous habitat with no adjacent neighbors. This would determine the relative importance of the presence of conspecifics on territorial spatial dynamics of birds.

Forest birds are of particular conservation concern because fragmentation can amplify the amount of edge habitat in a landscape, making small isolated forest islands less desirable for breeding (Robbins et al. 1989). The ecology of forest birds in fragmented habitats, however, likely results from a series of complex interactions at several spatial scales (Wiens 1989, Huhta et al. 1998). This leads us to question the definition of forest interior species based on edge use at the microhabitat level. Yahner (1988) states that interior species are those that should conduct most of their daily activities away from edges. However, social territorial behavior could confound "daily activities" related to forest edges. Hooded Warblers have traditionally been labeled as forest interior (Whitcomb et al. 1981, Evans-Ogden and Stutchbury 1994), but our comparison with space use in continuous forest indicates that males use the periphery of their territories more when territories are synonymous with forest edges. Evidence indicates that this is partially due to the absence of conspecifics but also may be a result of other benefits from forest edges such as improved foraging conditions or greater cover from predators.

Freemark and Collins (1992) reasoned that because forest-interior species, such as the Hooded Warbler, nest only within core forest area $(>100 \mathrm{~m}$ from the edge) and rarely occur near the edge, small fragments provide little suitable habitat. Their results support this conclusion: few forest species were found in fragments less than 10 ha. Our findings indicate that Hooded Warblers that breed in fragments less than 2 ha spend over one third of their time within $20 \mathrm{~m}$ of the edge. It would, therefore be misleading to conclude that Hooded Warblers avoid all small isolated fragments because of the immediate presence of forest edges.

\section{ACKNOWLEDGMENTS}

M. Stone, B. Fedy, and D. Buehler provided excellent field assistance. This research was supported by the Society of Canadian Ornithologists' Taverner Award, Kenneth G. Molson Graduate Fellowship, and York University Graduate Studies grants to DRN, the National Science and Engineering Research Council and the Premier's Research Excellence Award to BJMS. The manuscript was improved through valuable comments provided by P. Marra, I-A Bisson, B. Fedy, and R. Wagner. We also thank all the landowners in Crawford County, Pennsylvania who provided us with permission to work in their woodlots. 


\section{LITERATURE CITED}

Brittingham, M. C., and S. A. Temple. 1983. Have cowbirds caused forest songbirds to decline? BioScience 33:31-35.

Desrochers, A., S. J. Hannon., M. Bélisle, and C. C. St. Clair. 1999. Movement of songbirds in fragmented forests: can we 'scale up' from behaviour to explain occupancy patterns in the landscape? Proc. Int. Ornithol. Congr. 22:2447-2464.

Evans-Ogden, L. J., And B. J. Stutchbury. 1994. Hooded Warbler (Wilsonia citrina). In A. Poole and F. Gill [EDS.], The birds of North America, No. 110. The Academy of Natural Sciences, Philadelphia, and The American Ornithologists' Union, Washington, DC.

FERRIS. C. R. 1979. Effects of interstate 95 on breeding birds in northern Maine. J. Wildl. Manage. 43: 421-427.

Freemark, K. A., AND B. Collins. 1992. Landscape ecology of breeding birds in temperate forest fragments, p. 443-454. In J. M. Hagan III and D. W. Johnston [EDS.], Ecology and conservation of Neotropical migrant landbirds. Smithson. Inst. Press, Washington, DC.

Gates, J. E., AND L. W. Gysel. 1978. Avian nest dispersion and fledgling success in field-forest ecotones. Ecology 59:871-883.

GiRAlDEAU, L-A., AND R. YDENBERG. 1987. The centeredge effect: the result of a war of attrition between territorial contestants? Auk 104:535-538.

Huhta, E., J. Jokimaki, and P. Rahko. 1998. Distribution and reproductive success of the Pied Flycatcher Ficedula hypoleuca in relation to forest patch size and vegetation characteristics: the effects of scale. Ibis 140:214-222.

Kroodsma, R. L. 1984. Effect of edge on breeding bird forest species. Wilson Bull. 96:426-433.

MøLleR, A. P. 1991. Clutch size, nest predation, and distribution of avian unequal competitors in a patchy environment. Ecology 72:1336-1349.

MurCIA, C. 1995. Edge effects in fragmented forest: implications for conservation. Trends Ecol. Evol. 10:58-62.

Neudorf, D. L., B. J. M. Stutchbury, And W. H. Pip-
ER. 1997. Covert extra-territorial behaviour of female hooded warblers. Behav. Ecol. 8:595-600.

Noss, R. F. 1991. Effects of edge and internal patchiness on avian habitat use in an old-growth Florida hammock. Nat. Areas Journal 11:34-47.

Rappole, J. H., And A. R. Tipton. 1991. New harness design for attachment of radio transmitters to small passerines. J. Field Ornithol. 62:335-337.

Robbins, C. S., D. K. Dawson, And B. A. Dowell. 1989. Habitat area requirements of breeding forest birds of the middle Atlantic States. Wildl. Monogr. 103.

Sodhi, N. S., C. A. Paszkowski, And S. Keehn. 1999. Scale-dependent habitat selection by American Redstarts in aspen-dominated forest fragments. Wilson Bull. 111:70-75.

Stutchbury, B. J. M. 1998. Extra-pair mating effort of male hooded warblers (Wilsonia citrina). Anim. Behav. 55:553-561.

Weinberg, H. J., AND R. R. Roth. 1998. Forest area and habitat quality for nesting Wood Thrush. Auk 115:879-889.

Wenny, D. G., R. L. Clawson, J. FaAborg, and S. L. SHERIFF. 1993. Population density, habitat selection and minimum area requirements of three forest-interior warblers in central Missouri. Condor 95:968-979.

Whitcomb, R. F., C. S. Robbins, J. F. Lynch, B. L. Whitcomb, M. K. KLIMKIEWICZ, AND D. BYstraK. 1981. Effects of forest fragmentation on avifauna of the eastern deciduous forest, p. 125-205. In R. L. Burgess and D. M. Sharpe [EDS.], Forest island dynamics in man-dominated landscapes. SpringerVerlag, New York.

WIENS, J. A. 1989. Spatial scaling in ecology. Funct. Ecol. 3:385-397.

Wilcove, D. S. 1985. Nest predation in forest tracts and the decline of migratory songbirds. Ecology 66:1211-1214.

YAHNER, R. H. 1988. Changes in wildlife communities near edges. Conserv. Biol. 2:333-339.

YAHNER, R. H. 1995. Habitat use of wintering and breeding bird communities in relation to edge in an irrigated forest. Wilson Bull. 107:365-371. 